\title{
Die Suid-Afrikaanse Nasionale Vredesmag in Militêre Perspektief
}

\section{PROF LEO BARNARD EN ME SUNET SWANEPOEL Departement Geskiedenis, U.O.V.S., Bloemfontein}

\section{SUMMARY}

The release of Nelson Mandela in 1990 was the turning point in the democratisation process of South Africa, because the first free and fair election was declared in April 1994. This led to the establishment of the national Peace Force which had to assure that the first democratic election in the country would indeed be free and fair. The Peace Force was disrupted by various problems from the beginning. The first of which was the appointment of Gabriel Ramushwana as commander, who was no success. These problems were enhanced during the training process of the recrutes who would serve in the peaceforce. They not only had to be trained in the limited period of six weeks, which was impossible to achieve, but the fact that the recurters were associated with defferent structures and organisations, resulted in huge disagreements that could not be bridged. During the first deployment of the National Peaceforce, it was clear that they were not fit for the task and before long they disappeared into oblivion.

\section{DIE TOTSTANDKOMING EN ROL VAN DIE VREDESMAG}

Die vrylating van Nelson Mandela in 1990 was 'n keerpunt in die geskiedenis van Suid-Afrika. Dit het die weg gebaan vir die demokratiseringsproses in dié land. Onderhandelings tussen onder andere die Nasionale Party (NP) en die African National Congress (ANC) vir die hervorming van die Suid-Afrikaanse politieke bestel het 
reeds amptelik in Mei 1990 begin met die formulering van die Groote Schuur Minuut, waar beide F.W. de Klerk en Nelson Mandela hul tot vreedsame onderhandeling verbind het. ${ }^{1}$

$\mathrm{Na}$ vele onderhandelingspogings tussen 1991 en 1993 is daar uiteindelik gedurende die konstitusionele samesprekings by Kempton Park in 1993 besluit om 'n nuwe, demokratiese grondwet vir Suid-Afrika te formuleer en om 'n landwye demokratiese verkiesing op 27 April 1994 te hou. ${ }^{2}$

Die onderhandelaars was dit eens dat die NP-regering nie in beheer van die bestuur en toesig van die verkiesingsproses moes wees nie. Daar is besluit dat die verkiesing deur 'n onafhanklike verkiesingsliggaam, die Onafhanklike Verkiesingskommissie, bestuur sou word. Tesame hiermee is die Uitvoerende Oorgangsraad (UOR) geskep om, in oorleg met alle wetgewende en uitvoerende strukture op alle regeringsvlakke, die demokratiese oorgang in Suid-Afrika te verseker. Die UOR moes hoofsaaklik 'n klimaat skep wat gunstig sou wees vir 'n vry en regverdige verkiesing op 27 April 1994. ${ }^{3}$

Die bal vir die totstandkoming van 'n Nasionale Vredesmag (NVM), wat moes verseker dat Suid-Afrika se eerste demokratiese verkiesing vreedsaam verloop, is an die rol gesit toe die UOR by die Wêreldhandelsentrum die tot stand bring van so 'n mag in sy verslag aan die Veelparty Onderhandelingsforum op 2 Junie 1993 voorgestel het. Die voorstel het soos volg gelees:

"The Committee proposes the establishment of an independent peacekeeping force for the election. Its functions thereafter should be determined by the elected Government in consultation with relevant parties." 4

Na dié aanvaarding van hierdie voorstel van die UOR aan die Veelparty Onderhandelingsforum is daar stelselmatig begin om die strukture vir die daarstel van 'n vredesmag op die been te bring. 


\section{DIE BEVELSTRUKTUUR VAN DIE NASIONALE VREDESMAG}

Die Wet op die UOR is in September 1993 deur die parlement goedgekeur, waarvolgens die UOR aangestel is om toesig te hou oor die Nasionale Vreedesmag. Die UOR het op 7 Desember 1993 met sewe subrade in werking getree. Die verantwoordelikheid vir die vestiging van 'n Nasionale Vredesmag het berus by die agt lede van die Subraad oor Verdediging. Die lede was: mnr. W.N. Breytenbach, genl. A.J. Liebenberg, mnr. R. Kasrils, brig. L.M. Bengu, mnr. J. Modise, adv. A.S. Maake, prof. D.M.D. Mahlangu en brig. G. Ramushwana. ${ }^{5}$

Die Subraad oor Verdediging moes 'n Nasionale Vredesmag Bevelsraad (NVMBR), verteenwoordigend van alle militêre en polisieagentskappe wat aan die Nasionale Vredesmag wou deelneem, skep. Die medevoorsitters vir die Nasionale Vredesmag Bevelsraad was mnr. Lambert Moloi van MK en Lt. genl. J.H. Pretorius van die SAW. Die Subraad moes in oorleg met die Bevelsraad die volgende doen:

- 'n opleidingseenheid vir Nasionale Vredesmag-instrukteurs instel;

- die filosofie, leerstelsel, leerplan en opleidingsbeleid vir die Nasionale Vredesmag formuleer;

- $\quad$ kriteria vir werwing bepaal;

- standaard-operasionele prosedures vir die Nasionale Vredesmag bepaal;

- $\quad$ 'n dissiplinêre kode wat bindend sou wees vir die Nasionale Vredesmag, formuleer; en

- $\quad$ regulasies betreffende die magte en pligte van die Nasionale Vredesmag formuleer. ${ }^{6}$

Die eerste groot struikelblok wat die Nasionale Vredesmag teëgekom het, was die aanstelling van 'n bevelvoerder. Verdeeldheid tussen die SAW-elemente in die Nasionale Vredesmag en groepe verbind tot die ANC het die benoeming van die bevelvoerder van die Nasionale Vredesmag vertraag. Die twee kandidate was brig. George Kruys van die SAW en brig. Derek Mgwebi van die Transkeise Weermag. Mgwebi was 
volgens sekere offisiere van die SAW nie gekwalifiseer vir die posisie nie, terwyl die ANC weer van mening was dat dit onvanpas sou wees om 'n voormalige senior offisier van die Grensoorlog aan te stel as bevelvoerder van die Nasionale Vredesmag. ${ }^{7}$ Die Subraad het gevolglik op 'n kompromie-kandidaat in die vorm van brig. Gabriel Ramushwana besluit. In die proses het waardevolle dae verlore gegaan. Brig. Ramushwana was op daardie stadium die staatshoof van Venda en die hoof van Venda se Weermag. Brig. Ramushwana is op 24 Januarie 1994 deur die Subraad oor Verdediging aangewys, maar het eers op 7 Februarie 1994 met die rang van generaal-majoor in diens getree. ${ }^{8}$

Daar was groot kontroversie rondom Ramushwana se aanstelling. Die media het berig dat Ramushwana meer as R135 000 as 'n verlofuitbetaling onwettig ontvang het. Volgens die media het Ramushwana op 22 Oktober 1991, sowat agtien maande nadat hy die bewind in Venda in 'n staatsgreep oorgeneem het, aansoek gedoen dat ' $n$ jaar van sy vakansieverlof aan hom uitbetaal moes word. 'n Handgeskrewe tjek vir R135 275 is kort daarna aan Ramushwana oorhandig. Die Kommissie vir Administrasie in Venda het wel die moontlikheid om staatsamptenare se opgehoopte verlof uit te betaal ondersoek, maar daarteen besluit vanweë die groot finansiële implikasies wat dit sou meebring. ${ }^{9}$

Daar is ook berig dat Ramushwana ${ }^{10}$ twee jaar vantevore, vanweë ' $n$ verkeerde formule wat gebruik is by pensioenuitbetalings, 'n kitsmiljoenêr geword het. Sowat R1,2 miljoen is aan hom uitbetaal." Verder was Ramushwana 'n verkiesingskandidaat van die ANC vir die eerste algemene demokratiese verkiesing in die land se geskiedenis. Alhoewel hy sy kandidatuur onmiddellik met sy aanstelling onttrek het, het dit die IVP se kritiek van die sogenaamde partydige samestelling van die Nasionale Vredesmag net verder versterk. ${ }^{12}$

Hoofsaaklik vanweë die Nasionale Vredesmag Bevelsraad se besluit om die hoofkwartier van die Nasionale Vredesmag, nie soos verwag by die hoofopleidingskamp te De Brug in Bloemfontein te maak nie, maar by Kasteelpark in Pretoria, ${ }^{13}$ was Ramushwana feitlik nooit op De Brug teenwoordig nie. Dié besluit van die Nasionale Vredesmag Bevelsraad het Ramushwana dus van die fisiese ligging van sy bevel verwyder. Die 
afwesigheid van Ramushwana op De Brug was nie goed vir die moreel van Nasionale Vredesmag-lede nie.

In enige weermag speel die bevelvoerende offisier ' $n$ baie belangrike rol in die doeltreffende funksionering van daardie mag. Die bevelvoerder moet in staat wees om sekere moeilike besluit te neem, krisisse op te los en 'n eenheidsgevoel onder sy lede aan te wakker. Die aanstelling van die bevelvoerder van die Nasionale Vredesmag was dus een van die belangrikste take van die Nasionale Vredesmag Bevelsraad. Daarom bly dit steeds 'n raaisel waarom hulle met die naasbeste tevrede was. Die Nasionale Vredesmag moes elke keer tweede viool speel ter wille van die politieke magspel wat op daardie stadium aan die gang was.

Die Nasionale Vredesmag Bevelsraad was verplig om 'n lastige werkswyse in belang van inklusiwiteit en politieke balans aan te neem. Die Nasionale Vredesmag Bevelsraad kon nie net sy verantwoordelikhede na die bevelvoerder van die Nasionale Vredesmag delegeer nie. Die Nasionale Vredesmag Bevelsraad het gevolglik verskeie werkgroepe geskep - almal was polities gebalanseerd, waaronder een vir elk van die volgende aspekte: personeel, logistiek, opleiding, internasionale bystand, telekommunikasie, intelligensie, ens. Dié groepe het aanbevelings aan die Nasionale Vredesmag Bevelsraad gemaak, wat weer op sy beurt hierdie aanbevelings aan die Subraad oor Verdediging moes voorlê vir verwysing aan die bestuurskomitee van die UOR vir goedkeuring vanaf die UOR. Die bevelvoerder van die Nasionale Vredesmag is eers ná hierdie hele proses in kennis gestel. ${ }^{14}$

Om politieke redes moes die bevel- en ondersteuningspersoneel van die Nasionale Vredesmag "gebalanseerd" wees. Dit wil sê, indien die hoof van logistiek vanuit die SAW gekom het, moes sy adjunk of vanuit MK óf vanuit een van die ander magte kom. Dit het uiteindelik gelei tot 'n gebrek aan bekwame stafoffisiere. ${ }^{15}$

Die Nasionale Vredesmag het alle moontlike kundigheid benodig om doeltreffend te wees, daarsonder het hul reeds moeilike taak onmoontlik geword. 


\section{DIE SAMESTELLING VAN DIE NASIONALE VREDESMAG}

Soos met al die aspekte van die Nasionale Vredesmag was dit essensieel dat al die belangrikste partye, in die geval die polisie- en weermagte van dié partye, in die Nasionale Vredesmag verteenwoordig moes word. Al die groepe in Suid-Afrika moes hulself met die mag kon vereenselwig.

Volgens die Wet op die UOR moes die Nasionale Vredesmag bestaan uit lede van:

(i) alle militêre magte, sover doenlik in gelyke getalle, behalwe in soverre so ' $n$ mag verkies om minder lede tot daardie Mag by te dra; en

(ii) elke polisiëringsagentskap wat onder die gesag en beheer van ' $n$ deelnemer in die Raad val, wat in daardie Mag verteenwoordig wou word. $^{16}$

Die SAW en MK sou aanvanklik gelyke getalle tot die Mag voorsien, wat dan ongeveer twee derdes van die mag sou vul. Die res van die Nasionale Vredesmag sou bestaan uit verskeie ander militêre en polisiemagte. Die KwaZulu Polisiemag, die Bophuthatswana Weermag en Polisiemag was nie deel van die beplanning van die Nasionale Vredesmag nie. Die Nasionale Vredesmag het gevolglik bestaan uit lede van die SAW, SAP, MK, Weermag en polisiemagte van Transkei, Ciskei en Venda (TBVC state), asook lede van die polisiemagte van vyf van die ses nie-onafhanklike "nasionale state." ${ }^{17}$

Die plan was om 'n aanvanklike mag van ongeveer 4500 man te vestig wat in vier bataljonne, waarvan drie by De Brug en een by Koeberg in die Kaap, verdeel moes word. Elke bataljon moes uit vyf kompanies van 190 man bestaan en elke kompanie moes uit vyf pelotons met drie seksies per peloton bestaan. ${ }^{18}$ Elke peloton van 35 lede is saamgestel uit ongeveer agt lede vanuit die SAW, MK en Transkei (wat elk 'n bataljon na die Mag gestuur het), terwyl die oorblywende getalle gevul is deur lede van die SAP en TBVC-weermagte en -polisie wat elk 
kompanies na die Nasionale Vredesmag gestuur het. Vier en sestig vrouens van die SAW en MK en een van die Suid-Afrikaanse vloot sou deel vorm van 'n ondersteuningsgroep. ${ }^{19}$

\section{OPLEIDING VAN DIE NASIONALE VREDESMAG}

Na die voorstel van die Uitvoerende Oorgangsraad (UOR) aan die Veelparty Onderhandelingsforum vir die tot stand bring van ' $n$ Nasionale Vredesmag, is daar stelselmatig begin om die strukture vir die daarstel van 'n vredesmag op die been te bring. Die UOR is aangestel om toesig te hou oor die Nasionale Vredesmag. Die Wet op die UOR is in September 1993 deur die parlement goedgekeur. Die UOR het op 7 Desember 1993 met sewe subrade in werking getree. Die verantwoordelikheid vir die vestiging van 'n Nasionale Vredesmag het berus by die agt lede van die Subraad oor Verdediging. ${ }^{20}$

Aangesien die Nasionale Vredesmag in baie moeilike en gevaarlike omstandighede ontplooi sou word, was die formulering van 'n doeltreffende opleidingsbeleid een van die Subraad oor Verdediging se belangrikste take. Die Nasionale Vredesmag het intensiewe en omvangryke opleiding benodig om opgewasse te wees vir hulle taak.

Die Nasionale Vredesmag se opleidingstyd was baie beperk - te beperk as daar gekyk word na die opleidingsriglyne van een van die doeltreffendste onlusbeheereenhede in die wêreld, naamlik die Franse Compagnies Republicaines des Securite (CRS). Volgens senior lede van die Franse onlusbeheereenheid kon junior leiers (hoofsaaklik pelotonleiers) 'n snelkursus van slegs twee maande ontvang, maar dan benodig hulle vyf tot agt jaar geskikte ondervinding met 'n minimum skoolkwalifikasie van standerd agt. Kompaniebevelvoerders en senior offisiere kon in 'n maand opgelei word, maar dan benodig hulle tien jaar geskikte ondervinding en standerd tien. Die CRS benadruk die feit dat genoegsame ervaring nodig is vir die sukses van so 'n snelkursus. Cilliers en Mills ${ }^{21}$ het 'n voorgestelde snelkursus-skedule gebaseer op CRS riglyne vir reeds opgeleide lede (dit wil sê persone met die nodige ondervinding) opgestel. 
Die Suid-Afrikaanse beplanning vir 'n Nasionale Vredesmag het 'n nuwe standaard in korttermyn opleiding daargestel. Daar was geen preseleksieproses vir die leiers of ander lede in die Nasionale Vredesmag nie. Die resultaat was ' $n$ geweldige verskil in standaard. Die troepe van die Nasionale Vredesmag moes ten minste standerd agt en basiese militêre of polisie-opleiding hê. Dit was egter nie die geval nie. Sekere lede van MK was nie opgeleide soldate nie, maar lede van die Selfverdedigingseenhede ${ }^{22}$ in die "townships". Sommige MK-lede se opleiding was baie verroes, terwyl ander skaars kon lees of skryf. Aan die anderkant is baie van die SAW-lede beveel om vrywillig aan te sluit (volgens 'n ou militêre tradisie) en gelok met beloftes van beter betaling. ${ }^{23}$ Die SAW het 21 Bataljon (hulle was 'n hoogsopgeleide groep swart soldate wat effektief in die "grensoorlog" diens gedoen het.), gekoöpteer om deel te word van die Nasionale Vredesmag. ${ }^{24}$

Die instrukteurs van die Nasionale Vredesmag by De Brug en Koeberg het 'n opleidingskursus van twee weke onderneem. Die instrukteurs by De Brug is by die Pantserskool deur SAW-offisiere opgelei. Die offisiere wat by die opleiding betrokke was, is van hulle identiteit gestroop, met ander woorde hulle range was nie bekend nie. Hulle het hulle lesings in bruin oorpakke aangebied. Hulle het die instrukteurs van die Nasionale Vredesmag opgelei om die Nasionale Vredesmag-rekrute op te lei. ${ }^{25}$

Een analis het maande vantevore gewaarsku: "It may be possible to train rank-and-file members of the peacekeeping force in 4-6 months, but this is not true of officers. The officers of any police or peacekeeping force require specialized training and practical experience over a number of years." Wanneer 'n seksie of bataljon met 'n vyandige skare gekonfronteer word, word daar van die leier van so 'n groep verwag om sekere oordele te vel, soos byvoorbeeld of mag gebruik moet word, en indien wel, wanneer en hoeveel. Dit vereis 'n mate van sensitiwiteit en bekwaamheid wat slegs deur jare se opleiding en ervaring bekom kan word. Baie van diegene met junior en middelvlakbevelsposisies in die Nasionale Vredesmag het slegs beperkte opleiding gehad en nie genoeg veldervaring nie. $^{26}$ 
Hierdie Nasionale Vredesmag-instrukteurs moes na hul opleiding die nuwe Nasionale Vredesmag-rekrute vir vyf weke oplei. Hierdie periode is later met een week verleng, met ander woorde ses weke - 'n volle tien weke korter as wat deur kundiges voorgestel is. ${ }^{27}$ Die feit dat daar ten spyte van bepalings deur die UOR geen werwingskriteria vir lede van die Nasionale Vredesmag was nie, was 'n groot fout. Dit het veroorsaak dat die lede van die mag nie dieselfde standaard van opleiding gehad het nie. Ses weke was hopeloos te kort vir die opleiding van soldate met dieselfde militêre agtergrond, wat nog te sê van soldate met 'n uiteenlopende militêre agtergrond.

Voorts stel deelname aan 'n vredesmag algehele nuwe vereistes aan manskappe wat hoofsaaklik opgelei is vir "oorlog". Van 'n vredesmag word verwag om vrede met die minimum gebruik van mag te bewaar. Alle Nasionale Vredesmag-lede het dus ondanks hul voormalige opleiding, intensiewe opleiding in sake soos bemiddeling, onderhandeling en konsensusvorming benodig.

Die opleiding van die troepe is in drie hoofopleidingsmodules verdeel. Die eerste module het die doel van die mag, die struktuur daarvan, die gedragskode, Vredesverdrag, en die verkiesingsproses gedek. Dit is gevolg deur module twee wat gefokus het op driloefeninge, die gebruik van wapens, kommunikasie, onderhandelingsvaardighede en noodhulp. Die grootste deel van die kursus is aan module drie afgestaan wat gefokus het op skarebeheer, vredesbewaringstegnieke, padblokkades, ens. $^{28}$ In isolasie lyk dit na 'n goeie opleidingsprogram, maar binne die sesweekopleidingsperiode kon daar nie aan enige van die modules behoorlik aandag geskenk word nie.

In Maart 1994 het senior offisiere van die Nasionale Vredesmag by De Brug, Koeberg en Pretoria werkswinkels oor vredebewaring in Kaapstad, Johannesburg en Durban bygewoon. Die doel van die werkswinkels was onder meer om die offisiere van die Nasionale Vredesmag met konflikresolusievaardighede toe te rus sodat hulle interne konflik wat in so 'n gesamentlike mag kan ontstaan, beter kon hanteer. ${ }^{29}$ Die verskillende militêre kulture, veral tussen die SAW en die gewapende magte van die TBVC-state aan die een kant, en MK aan die ander kant, en ook die kultuurverskille tussen die polisie en die weermag, 
het aanleiding gegee tot baie probleme. ${ }^{30}$ Die was onsinnig om te verwag dat voormalige vyande oornag ' $n$ samehorige mag moes vorm.

\section{INTERNASIONALE BYSTAND}

Volgens die meeste partye betrokke by die totstandkoming van die Nasionale Vredesmag was een of ander vorm van internasionale deelname aan die Nasionale Vredesmag baie belangrik. Die internasionale gemeenskap het geweldig baie ondervinding aan die hand van $\mathrm{VN}$-vredesmagprojekte gehad. Dit was kundigheid wat van groot waarde vir die Nasionale Vredesmag kon wees.

Internasionale betrokkenheid by die opleiding van die Nasionale Vredesmag was volgens die Wet op die UOR verpligtend:

Die Subraad moet, in oorleg met die Nasionale Vredesmagbevelsraad, met ... - 'n opleidingseenheid vir Nasionale Vredesmaginstrukteurs instel en omsien na die opleiding van daardie instrukteurs, wat gewerf kan word uit die deelnemende militêre magte en polisiëringsagentskappe, maar wat ook buitelandse deskundiges moet insluit. ${ }^{3 I}$

Volgens Cilliers en Mills moes internasionale bystand die volgende vier elemente bevat:

- kundige beleidadvies betreffende die struktuur van bevel, operasionele en opleidingsdoktrine;

- bystand met die seleksie van vredesmaglede;

- die verskaffing van opleiding vir die Suid-Afrikaanse opleidings-kontingent; en

- voortgesette toesig en opknappingskursusse (insluitende oorsese besoeke en kursusse) vir ' $n$ aansienlike periode nadat die opleiding afgehandel is. ${ }^{32}$ 
Vir voormalige MK-vredesmaglede was neutrale instrukteurs, dit wil sê internasionale hulp, baie belangrik omdat hulle nie deur hul voormalige vyand, die SAW, opgelei wou word nie. ${ }^{33}$

Vyf dae voordat opleiding geskeduleer was om te begin, het die UOR ' $n$ formele beroep op die Statebond Sekretariaat vir bystand met die opleiding van die Nasionale Vredesmag en vir die evaluering van die mag gerig. Gegewe die tydsbeperking was die byeenbring van 33 senior militêre en polisie offisiere vanuit sewe lande 'n merkwaardige prestasie. ${ }^{34}$ Die statebond sou aanvanklik 'n kontingent aan beide De Brug en Koeberg verskaf, maar 'n daaropvolgende ooreenkoms met Frankryk het beteken dat die Commonwealth Peacekeeping Assistance Group (CPAG) tot De Brug beperk is. ${ }^{35}$

Frankryk het aanvanklik ingestem om (in Februarie) 'n opleidingspan bestaande uit tien lede van die Franse Nasionale Polisie te stuur met die doel om 100 instrukteurs vir die Nasionale Vredesmag op te lei. Dit het aan die Nasionale Vredesmag sekere probleme besorg, omdat daar nie voldoende tyd was om die instrukteurs voor die werklike opleidingsperiode op te lei nie. Opleiding van die instrukteurs moes feitlik parallel met dié van die Nasionale Vredesmag self plaasvind. Die uiteindelike versoek aan Frankryk is gevolglik verminder na slegs ses instrukteurs. Hulle het op 4 Maart by Koeberg aangekom en weer op 11 April 1994 vertrek. $^{36}$ Die Subraad oor Verdediging en die Nasionale Vredesmag Bevelsraad het vir ' $n$ wonderwerk gehoop, want nie eers hoogs opgeleide Franse instrukteurs kon 'n vredesmag binne vier weke oplei nie.

Die eerste groep Commonwealth Observer Mission for South Africa (COMSA) instrukteurs vanaf Brittanje, Indië, Kanada, Botswana en Zimbabwe het op 6 Februarie 1994 by De Brug aangekom. Die groep was onder die bevel van kol. Nick Cottam van die Verenigde Koninkryk. Die CPAG het die belangrikheid om die vertroue van die publiek as ' $n$ middel om geweld te beheer en die geloofwaardigheid van die Nasionale Vredesmag te bevorder, regdeur die kursus beklemtoon. Verder, as deel van gemeenskapspolisiëring, is 'n probleemoplossingsbenadering aanbeveel. Die CPAG-span wou veral die vlak van geweld wat tradisioneel deur SAW-lede in swart woongebiede ingespan is, 
verminder. In ooreenstemming hiermee het hulle daarin geslaag om die Nasionale Vredesmag te oorreed om weg te doen met hul haelgewere om sodoende burgerlike sterfgevalle te verminder. Hulle kon egter nie daarin slaag om 'n einde te maak aan die praktyk om gewapen met 'n semi-outomatiese geweer by 'n toneel op te daag nie. Volgens die CPAG sou so 'n veglustige houding eerder geweld aanhits as wat dit geweld sou inhibeer. Streng reëls vir die gebruik van mag is deur CPAG-instrukteurs neergelê. Mag moes slegs gebruik word wanneer waarskuwings om orde te herstel, nie geslaagd was nie. ${ }^{37}$

Alhoewel beide die Franse span en die CPAG 'n substansiële bydrae tot die opleiding van die Nasionale Vredesmag gelewer het, was daar tog die gevoel dat hulle nie werklik 'n aanvoeling/toegeneentheid vir die Suid-Afrikaanse kultuur gehad het nie. Volgens kol. Van Heusden kon daar nie verwag word dat mense wat nie eens die taal kon praat nie, Vredesmaglede moes oplei nie. ${ }^{38}$ Lt.kol. Lubbe was verder van mening dat hierdie internasionale instrukteurs die verkeerde tipe opleiding aangebied het. Vredesmaglede is byvoorbeeld geleer om skarebeheer in kolonne toe te pas. Dit behels dat die troepe in kolonne vorentoe beweeg, totdat fisiese kontak gemaak word, waarna die skare teruggedryf word. Volgens lt.kol. Lubbe is dit standaard skarebeheer-opleiding, maar was dit nie geskik in die swart woongebiede waar troepe teen 'n gewapende skare van tussen 2000 en 3000 te staan sou kom nie. ${ }^{39}$ 'n Mens kon dus kwalik verwag dat hulle rekrute kon oplei om dié hoogs problematiese proses die hoof te bied. Vredesmaglede is dus nie voldoende opgelei om onder effektiewe wapenvuur op te tree nie.

\section{DIE DE BRUG-INNAME}

Kol. Fred Burger van die SAW was in die afwesigheid van die UOR se aangestelde bevelvoerder die waarnemende offisier in beheer van De Brug. Die opleiding van die opleidingspan van 47 lede (die eerste De Brug-inname het eintlik 'n opleidingspan van tussen 120 en 150 instrukteurs benodig), het op 9 Januarie 1994 begin. Die leiersgroep het op 16 Januarie by De Brug aangekom en het vanaf 16 tot 23 Januarie 1994 oriënteringsopleiding ontvang, dit wil sê hulle is geleer hoe om die 
Nasionale Vredesmag-rekrute op te lei. Die hoofmag wat op 24 Januarie verwag is, het twee dae te vroeg opgedaag en gevolglik alle voorbereidings vir hulle ontvangs onkant gevang. ${ }^{40}$

Probleme tydens die inname van Nasionale Vredesmag-lede op De Brug was legio. Die inname-proses is geheel en al deur die SAW (Vrystaatse Kommandement) hanteer, omdat daar nog nie 'n vredesmaginfrastruktuur was om vredesmaglede te ontvang nie. ${ }^{41}$ Die dokumentasie van die inname op De Brug het in tente geskied. Daar was geen rekenaars nie en alles moes met die hand gedoen word. Die SAW het nie naamlyste vanaf die verskillende magte ontvang nie. Hulle het dus geen manier gehad om te bepaal wie daar moes wees en wie nie. Daar was ook geen range betrokke nie en die verskillende magte is gevolglik deurmekaar gedokumenteer. Selfsaamgestelde magsnommers is aanvanklik aan die lede toegeken. Daar was taalprobleme, veral met die voltooiing van die onderskeie vorms. Die SAW-personeel het ook probleme ondervind om aan Vredesmaglede te verduidelik dat hulle 'n testament moes opstel as deel van standaard militêre prosedure. ${ }^{42}$ Die SAW moes sy eie dokumentasie gebruik, omdat hulle geen dokumente vanaf die Nasionale Vredesmag self ontvang het nie. Gevolglik was baie Vredesmaglede ontstoke omdat daar bo-aan die inklaarvorms "Welkom in die SAW" gestaan het. ${ }^{43}$

Verdere administratiewe probleme het ontstaan omdat sommige van die MK-lede hulle "gevegsname" (Nome de guerre) in plaas van hulle regte name gebruik het. Sonder identiteitsdokumente kon daar nie bankrekenings geopen word nie en sonder bankrekenings moes salarisse met die hand in die basis uitbetaal word. 'n Vergelyking tussen die besoldiging van persone van verskillende gewapende magte, maar met gelyke rang, was in die omstandighede onafwendbaar. De Brug het verder verwag dat al die lede van die mag medies geskik sou wees, maar dit was nie die geval nie. Binne ' $n$ week moes ongeveer sestien lede ontslaan word vanweë verskeie siektes soos Tuberkulose en dies meer. ${ }^{44}$

Die De Brug opleidingskamp het hoogstens akkommodasie vir 3 350 manskappe gehad - dit was die getal wat aanvanklik verwag is. In plaas hiervan moes die kamp 3740 rekrute huisves, hoofsaaklik vanweë 'n addisionele 440 polisiemanne vanaf Transkei. Die Nasionale 
Vredesmag Bevelsraad het gevolglik besluit om die Transkei weermag en polisie te verminder. Toe 439 Transkei-lede teruggestuur is, het 55 lede van die Transkei polisie hulle sonder toestemming vergesel. Hierdie tendens het algemeen voorgekom. ${ }^{45}$ Dwarsdeur hul verblyf op De Brug het Nasionale Vredesmag-lede na willekeur gekom en gegaan.

Verskeie ander probleme het ook ontstaan. So byvoorbeeld het die Transkei Weermag 240 onderkorporaals - 'n uitgebreide getal - gestuur wat 'n addisionele finansiële las veroorsaak het. Slegs die SAW het seinoffisiere voorsien en daar was 'n tekort aan logistieke personeel. 'n Verdere probleem was die range van die MK-lede. Daar was nie 'n eenvormige standaard vir die toekenning van range nie. MK het nie die Westerse rangsisteem gevolg nie en gevolglik het persone se range oornag verander. ${ }^{46}$ Volgens 'n lid van die SAW was daar ten minste 'n neëntienjarige sersant-majoor ${ }^{47}$ en 'n een-en-twintigjarige regimentsersant-majoor onder MK-lede. ${ }^{48}$

In 'n normale leërsituasie neem dit tussen twaalf en vyftien jaar vir 'n soldaat om tot die rang van sersant-majoor bevorder te word. Om in aanmerking te kom vir hierdie bevordering sou die betrokke soldaat bepaalde opleidingskursusse moes bywoon. Die MK-soldate was afkomstig vanaf 'n onkonvensionele leër. MK-soldate is hoofsaaklik in buurstate opgelei en die tipe opleiding wat hulle ontvang het, het baie verskil van enige konvensionele weermagopleiding. ${ }^{49}$ Dit is dan ook voor die hand liggend dat hul rangtoekennings nie volgens normale voorskrifte geskied het nie.

Die probleem hiermee was egter dat MK-soldate streng gesproke in die SAW - 'n konvensionele leër met konvensionele strukture - opgeneem is. Hulle onkonvensionele werkswyse sou dus moes verander, aangesien daar in 'n konvensionele leër soos die SAW sekere kwaliteite aan die rang van sersant-majoor geheg word, waaronder leierskapseienskappe en voldoende ervaring en opleiding.

Hierdie probleme is onnodig vererger deur 'n geweldige getal besoekers by die De Brug-area, waaronder die media, wat alles in hulle vermoë gedoen het om inligting in verband met die Nasionale Vredesmag te bekom. Daar was selfs 'n voorval waar 'n televisiespan deur die Militêre Polisie gearresteer is, omdat hulle militêre gebied sonder 
toestemming betree het. Hulle het die basis deur die veld binnegekom en die Nasionale Vredesmag op 'n koppie afgeneem. Die Nasionale Vredesmag het wêreldnuus geraak. Daar was ongeveer 157 mediaverteenwoordigers van regoor die wêreld (Duitsland, New York, Taiwan, ens.) wat verslag gedoen het oor die Nasionale Vredesmag. ${ }^{50}$

Die grootskaalse mediadekking van die Nasionale Vredesmag het onrealistiese verwagtinge geskep. Die Nasionale Vredesmag is aanvanklik met groot entoesiasme begroet, wat geleidelik oorgegaan het tot kritiek soos wat die liggaam gefaal het om aan die vewagtinge te voldoen. Mediadekking was dus 'n tweesnydende swaard. Aan die een kant het dit 'n gunstige indruk geskep dat die land se besluitnemers reageer op plaaslike probleme en aan die ander kant het dit onrealistiese verwagtinge geskep.

Met die aanvang van opleiding op De Brug het die Nasionale Vredesmag uit die volgende lede bestaan:

- 927 SAW-lede;

- 863 lede van die Transkei weermag;

- 440 lede van die Transkei-polisiemag (daar is nie vir hulle beplan nie);

- 256 lede van die Ciskei-weermag (32 meer as waarvoor beplan is);

- 188 lede van die Venda-weermag (23 minder as waarvoor beplan is);

- 197 vanaf die SAP (23 minder as waarvoor beplan is);

- $830 \mathrm{MK}-\mathrm{lede}$; en

- 29 polisiemanne vanaf Qwa-Qwa, Kangwane, Ciskei, Venda en Gazankulu, waarvoor daar nie beplan is nie. ${ }^{51}$

Die Nasionale Vredesmag by De Brug kon glad nie op die been kom nie. Ontnugtering met dié mag het gespruit uit 'n reeks ontstellende voorvalle, waaronder die hoogs gepubliseerde gebeurtenis op Saterdag 29 Januarie toe ongeveer 600 voormalige MK-lede, baie van hulle dronk, getoyi-toyi het en PAC-slagspreuke soos "one settler, one bullet", "kill the boer, kill the farmer" en "down with F.W. de Klerk", gesing het en 
ander lede van die mag (veral blanke lede) geviktimiseer het. ${ }^{52}$ Baie Nasionale Vredesmag-lede het in die veld gaan slaap in plaas van in hulle tente, omdat hulle vir hul lewe gevrees het. Hierdie insident het die beeld van die Nasionale Vredesmag baie skade berokken. Op 17 Februarie het 'n SAMIL-vragmotor omgeval, waarskynlik vanweë die feit dat die voertuig oorlaai was en die bestuurder na bewering dronk was. Verder het vredesmaglede sonder toestemming verlof geneem, gestaak weens griewe oor salarisse en was hulle selfs betrokke in 'n dronkmansbakleiery in Bloemfontein se middestad. Vredesmaglede was traag om van verlof af terug te keer en het in baie gevalle vredesmagvoertuie vir dié doel gebruik. ${ }^{53}$

Volgens lt.kol. Lubbe het Nasionale Vredesmag-lede eenvoudig Vredesmagvoertuie by die dieselbunkers volgemaak en daarmee met verlof vertrek. Van die tien voertuie wat lt.kol. Lubbe langs die pad gestop het, het slegs twee magtiging gehad om die basis te verlaat. Agter in dié voertuie het vyf of ses vredesmaglede gesit met dromme brandstof in die middel. ${ }^{54}$ Minstens vyftien voertuie van die Nasionale Vredesmag is tydens hierdie verloftydperk vermis. Baie vredesmaglede het ook die kampterrein 'n dag voordat hulle amptelike verlof begin het, verlaat. ${ }^{55}$

Bogenoemde gebeure en die ongunstige mediadekking het die moreel van die mag ondermyn. Bedankings uit die mag het toegeneem en teen Maart 1994 het daar reeds 187 lede bedank.

\section{PROBLEME BY DE BRUG}

Probleme in die Nasionale Vredesmag te De Brug kan soos volg opgesom word:

- Die integrasie van 'n mag uit dertien verskillende groepe. Dit is deur die jare oor en oor bewys dat dit 'n formidabele uitdaging is om 'n enkele, verenigde, gedissiplineerde mag uit uiteenlopende gewapende formasies met uiteenlopende tradisies, opleiding en agenda's saam te smee. Dit is veral die geval wanneer daar, soos met die Nasionale Vredesmag, gepoog word om onlangse vyande saam te smelt. ${ }^{56}$ 
- $\quad$ 'n Afkeer onder lede van die SAW, SAP en tuislandmagte, as gevolg van hul werwingsomstandighede.

- $\quad$ 'n Probleem in verband met salarisse..$^{57}$

- Die ongepaste gradering van sommige offisiere tot senior rang. Volgens lt.kol. Lubbe is van die MK-lede as sersante en sersant-majoors aangestel sonder dat hulle die rang verdien het. Dit was slegs range wat vir vredesmagdoeleindes aan hulle gegee is. ${ }^{58}$

- Die indruk dat die SAW (a) traag was met die verskaffing van toerusting, soos gepantserde voertuie, (b) dat nóg die SAW nóg die SAP hul beste opleidingsinstrukteurs gestuur het, (c) swak logistieke steun - tekort aan bestuurders, kokke, tegniese steun, ens. ${ }^{59}$

- Die fasiliteite op De Brug was nie voldoende vir drie bataljonne nie. Vredesmaglede is in tente op die skietbaan gehuisves. Daar was veral 'n tekort aan badfasiliteite. Daar is wel mobiele storte geïnstalleer, maar as gevolg van etlike probleme, waaronder finansies en die feit dat die Departement Openbare Werke nooit van die grond af gekom het nie, het hierdie storte nie gewerk nie. Volgens Lubbe was daar wel 'n higiëne-probleem. ${ }^{60}$ Daar was slegs een badkamer vir elke 200 troepe. Gevolglik het baie troepe hulself uit brandemmers gewas. Vredesmaglede het ook in die wasbakke geürineer en hulle in die storte ontlas. Daar was 40 aangemelde gevalle van malaria, 100 gevalle van geslagsiektes en ongeveer 50 gevalle van tuberkulose. ${ }^{61}$

- Die opleiding was nie op standaard nie. Baie van die instrukteurs, veral MK-instrukteurs, het nie geweet hoe om troepe op te lei nie en die opleidingstydperk was ook hopeloos te kort. $^{62}$

Die grootste probleem was egter die gebrek aan 'n wetlike ondersteuningsplan vir die Nasionale Vredesmag. Sonder wetlike magte was daar nie ' $n$ basis vir die diensvoorwaardes vir die lede van die Nasionale Vredesmag nie en ook nie 'n dissiplinêre kode nie. Dit was 
eers ná probleme met vredesmaglede dat die UOR 'n dissiplinêre en gedragskode gefinaliseer het en in die Staatskoerant van 21 Februarie 1994 gepubliseer het. Dié regulasies het onmiddellik in werking getree. ${ }^{63}$ Alle vredesmaglede moes ' $n$ belofte onderteken om getrou te bly aan die gedrags- en dissiplinêre kode. Volgens die dissiplinêre kode was die volgende gedragsoortredings:

- afwesigheid sonder verlof;

- versaking van pligte;

- $\quad$ ongehoorsaamheid;

- wanordelike gedrag;

- die rig van vuurwapens op ander lede van die Nasionale Vredeśmag;

- vandalisme;

- die gebruik van dwelms;

- dronkenskap; en

- om die belange van 'n politieke party te bevorder. ${ }^{64}$

Die straf vir oortreders wat voor 'n verhooroffisier moes verskyn, het die volgende ingesluit:

- $\quad$ 'n R300 afkoopboete;

- $\quad$ 'n boete van tot R2000 (aftrekbaar van 'n lid se salaris);

- inperking tot die barakke vir 30 dae;

- ekstra pligte; of

- $\quad$ 'n lid kon teruggestuur word na sy mag van oorsprong. ${ }^{65}$

'n Normale weermag mak meer staat op 'n korpsgees (esprit de corps) vir interne samehorigheid as op die dreigement van resgprosedure. In die afwesigheid van 'n geïntegreerde militêre kultuur het slegs dwang oorgebly. Nadat vredesmaglede die gedragskode onderteken het, het die dissipline verbeter. ${ }^{66}$ 


\section{EVALUASIE VAN DIE DE BRUG KONTINGENT}

'n Polities gebalanseerde evalueringspan het die De Brug kontingent tussen 21-25 Maart 1995 geëvalueer. Die span was onder die koördinering van die Direkteur van Opleiding van die SAW en het bestaan uit lede van die CPAG, Transkei-weermag, SAW, MK, SAP en Venda-weermag. ${ }^{67}$ Die evalueringsoefeninge waaraan die Nasionale Vredesmag onderwerp is, het onder meer die volgende ingesluit: hulle moes rookgevulde tente bestorm, ' $n$ aggressiewe skare by ' $n$ gesimuleerde stemlokaal afweer en na 'n bende "rowers" wat die "verkiesing" wou ontwrig, skiet. ${ }^{68}$

Die evalueringspan het slegs drie "sterk punte" geïdentifiseer:

- Ten spyte van beperkinge en 'n gebrek aan riglyne vanaf Brigade Hoofkwartier het die bataljonne voortgegaan met opleiding;

- Die positiewe impak van die CPAG-lede op die opleiding; en

- die bereidwilligheid van meeste van die troepe om te leer.

Hierdie drie punte is gevolg deur 22 "swak punte". Van die "swak punte" wat deur die evalueerders geïdentifiseer is, was:

- probleme met bevel en beheer deur offisiere, adjudant-offisiere en onderoffisiere;

- lede van sommige afvaardigings het nie 'n aanvoeling vir militêre dissipline en ontplooiingsoefeninge gehad nie;

- $\quad$ 'n gebrek aan motivering vir die taak;

- $\quad$ 'n gebrek aan waardering vir die skare tydens onlusbeheer;

- $\quad$ swak riglyne vanaf Brigadehoofkwartier;

- $\quad$ onvoldoende logistieke steun aan opleiding vanweë 'n gebrek aan gasmaskers en luidsprekers;

- $\quad$ beperkinge ten opsigte van opleidingstyd;

- $\quad$ 'n Gebrek aan opleidingservaring deur die leiersgroep; 
- ontoereikende grootte van die opleidingspan; en

- 'n gebrek aan leierskapsvaardighede. ${ }^{69}$

Opsommend het die evalueringspan bevind dat Bataljonne Een en Drie (met die uitsondering van twee kompanies wat ontplooi kon word), aansienlike heropleiding benodig het. Bataljon Twee, onder leiding van lt.kol. Quinton Painter, was gereed vir ontplooiing na geringe heropleiding. As 'n resultaat sou Bataljon Twee en twee kompanies van Bataljon Drie op 11 April 1994 ontplooi word. Die res moes weer opgelei word en sou op 23 April ontplooi word. Die heropleiding van bataljonne Een en Drie is egter vertraag omdat soldate nie betyds van hulle verlof af teruggekeer het nie. ${ }^{70}$

\section{DIE INNAME'BY KOEBERG}

Soos reeds genoem, is daar besluit om een bataljon van die Nasionale Vredesmag by die polisie-opleidingsterrein te Koeberg naby Kaapstad op te lei. Volgens die Nasionale Vredesmag Bevelsraad sou die mag by Koeberg uit een bataljon (vyf operasionele kompanies), 'n totaal van 1062 (later 1200) persone uitmaak. Vanweë beperkinge ten opsigte van die beskikbaarheid van badfasiliteite het die Koeberg inname slegs 22 vroue ingesluit. Die meeste van hulle het deel uitgemaak van die mediese eenheid. ${ }^{71}$

Die getalle van die verskillende groepe was soos volg:

- SAW 251;

- Transkei weermag 188 en polisie 161 ;

- $\quad$ MK 246;

- $\quad$ SAP 36;

- Venda polisie 20; en

- die polisiemagte van Kangwane vyf; Kwandebele 26, Lebowa 39 en Qwa Qwa 32. ${ }^{72}$

Sake het hier heelwat beter verloop as op De Brug. Die redes hiervoor was onder meer die feit dat die MK-kontingent by Koeberg 
bykans almal van Tanzanië afkomstig was. In kontras met die situasie op De Brug, was hulle goed gedissiplineerd, opgelei en georganiseerd. Dit op sigself het baie van die probleme wat by De Brug ondervind is, uitgeskakel. ' $n$ Tweede rede vir die hoër moreel en standaard by Koeberg was as gevolg van die uitstekende fasiliteite. Beide die woonkwartiere (lede is in kamers gehuisves) en die ontspanningsfasiliteite was beter as op De Brug. ' $n$ Moontlike derde rede was dat Koeberg nie soveel aandag van die media getrek het nie. ${ }^{73}$

In teenstelling met die De Brug kontingent wat hoofsaaklik deur weermaglede opgelei is, is die Koeberg-kontingent hoofsaaklik deur lede van die polisie opgelei. Opleiding het gladder verloop en volgens die evaluasie wat tussen 8-9 April plaasgevind het, kon hulle na geringe heropleiding ontplooi word. Dié groep is egter nooit ontplooi nie.

\section{DIE ROL VAN DIE NASIONALE VREDESMAG IN DIE ALGEMENE VERKIESING VAN 1994}

Die behoefte aan 'n vredesmag het gespruit uit Suid-Afrikaners, veral die politici, se begeerte vir 'n vreedsame verkiesing op 27 April 1994. Die Nasionale Vredesmag is dus geskep om 'n baie definitiewe funksie te vervul, naamlik die handhawing van vrede tydens die verkiesing.

Die Nasionale Vredesmag was 'n neutrale liggaam van soldate waarin voormalige vyande verenig is en belas is met die bewaring van vrede. Dit moes stabiliteit binne die land verseker voor en tydens die verkiesing van April 1994. ${ }^{74}$ Volgens genl. Ramushwana was die Nasionale Vredesmag 'n para-militêre mag wat gebruik sou word om geweld en misdaad te voorkom en stabiliteit te handhaaf. Dit sou ook die handhawing van wet en orde beheer en lede van die gemeenskap bystaan. $^{75}$

In die afwesigheid van 'n definitiewe pligtestaat vir die Nasionale Vredesmag, was daar 'n element van dubbelsinnigheid oor sy funksie sou die Nasionale Vredesmag vrede bewaar ("peacekeeping") of vrede "afdwing" ("peace-enforcement")? 
Vredebewaring is die stuiting en/of beëindiging van vyandigheid tussen of binne state deur die medium van 'n onpartydige derde party van militêre magte en burgerlikes wat internasionaal georganiseer en gelei word om vrede te herstel. ${ }^{76}$ Dit hou oor die algemeen verband met 'n situasie waar 'n skietstaking in werking getree het en waar die betrokke hoofpartye hulp benodig in die bewaring van ' $n$ wankelrige vrede. Vredebewaringsmagte is nie swaar gewapen nie en hulle doel is om 'n mag tussen die voormalige vyande te ontplooi om letterlik die vrede tussen die groepe te bewaar. ${ }^{77}$ Kontemporêre vredebewaring kan onder meer die volgende behels:

- verkiesingsteun;

- voorkomingsontplooiing;

- die skeiding van vyandige magte, hul demobilisasie en die versamel en/of vernietiging van wapens;

- die vestiging van veilige omstandighede vir die verskaffing van humanitêre hulp; en

- die ontwapening van para-militêre magte. ${ }^{78}$

Die afdwing van vrede is ' $\mathrm{n}$ aksie waartydens militêre middele gebruik word om vrede in 'n area van konflik te herstel. Dit kan interstaatlike of intrastaatlike konflik behels of gebruik word wanneer staatsinstellings grootliks ineengestort het. ${ }^{79}$ Hierdie sendings word onderneem in 'n omgewing waar konflik steeds heers. Hulle doel is eerder om vrede af te dwing as om dit te bewaar. Vir so 'n taak word goed toegeruste eenhede benodig en hul sending is in baie opsigte gelyk aan 'n militêre veldtog. Die toestemming van die partye betrokke by die konflik word nie vereis nie en die vyandelikhede hoef nie amptelik beëindig te wees nie. ${ }^{80}$

Die Subraad oor Verdediging en die publiek was van mening dat die Nasionale Vredesmag se rol een van vredebewaring moes wees. 'n Konsep wat ontleen is aan die VN se sogenaamde "blue beret"-praktyke in onder andere Namibië (UNTAG), Somalië en Kamóodja. Die Nasionale Vredesmag is geskep met die klem op 'n militêre vaspenaksie eerder as die herstel van wet en orde in areas soos die Oos-Rand. In 
plaas daarvan om middele te soek om die funksie van gemeenskapsordepolisiëring te wettig, het Suid-Afrika slegs sy bestaande probleme met geweld vererger. Die rede hiervoor het verband gehou met die politieke ooreenkoms tussen die ANC/MK en die Suid-Afrikaanse Regering/SAW, asook die vyandigheid van die ANC en die publiek teenoor die $\mathrm{ABS}^{81}$

Die Nasionale Vredesmag sou in werklikheid beide vrede moes bewaar en afdwing. Wat die afdwing van vrede betref, moes die mag konfrontasie/konflik in die areas wat die meeste deur geweld geraak is, voorkom. Hulle moes ook tussenbeide tree in die geval van fisiese geweld (met 'n minimum gebruik van mag) en hulle moes opstokers in hegtenis neem. ${ }^{82}$

In terme van vredebewaring was dit die mag se verantwoordelikheid om hulself duidelik sigbaar te maak deur die aktiewe patrolering van woongebiede. Hulle moes ook die politieke speelveld gelyk stel, vrye politieke aktiwiteite beskerm, asook koördinasie en interaksie met die Nasionale Vredesekretariaat ${ }^{83} /$ internasionale monitors handhaaf. Die Nasionale Vredesekretariaat is geskep om die oorsake en die verskynsel van politieke geweld en intimidasie doeltreffend te hanteer, en om maatskaplik-ekonomiese heropbou en ontwikkeling na konflikbeslegting te fasiliteer. Spesifieke komitees is vir hierdie doel ingestel. Die Nasionale Vredesmag het laastens ook 'n sekondêre funksie gehad wat uitgevoer moes word wanneer omstandighede dit toegelaat het. Dit was om deel te neem aan nasie-bou deur byvoorbeeld humanitêre bystand tydens 'n krisis en deelname aan gemeenskapsopheffing. ${ }^{84}$ Die ontplooiing van die Nasionale Vredesmag was egter van te korte duur vir hulle om by enige nasie-bou-aktiwiteite betrokke te raak.

\section{ENKELE SLOTGEDAGTES}

Die verkiesingssperdatum van 27 April 1994 het dit vir die Nasionale Vredesmag Bevelsraad baie moeilik gemaak om die Nasionale Vredesmag betyds gereed te kry. 'n Lang komplekse bevelsketting, waaronder die bevelvoerder van die Nasionale Vredesmag, die Nasionale Vredesmag Bevelsraad, ${ }^{85}$ die Subraad oor Verdediging, die 
bestuurskomitee van die UOR en uiteindelik die UOR, tesame met die feit dat al die deelnemende politieke partye se goedkeuring vir elke besluit verkry moes word, het beteken dat besluitneming 'n lang uitgerekte proses was. Die gevolg was dat die werklike aktivering van die Nasionale Vredesmag te lank gesloer het. ${ }^{86}$

Die beplanning en voorbereiding vir die Nasionale Vredesmag was nie voldoende nie. Die strukture van die Nasionale Vredesmag was nie behoorlik gevestig nie. Logistieke, finansiële en personeelstrukture was veronderstel om in plek te wees voor die inname van vredesmaglede; ${ }^{87}$ dit was egter nie die geval nie, soos die gebrek aan 'n dissiplinêre kode ook getuig het. 'n Dissiplinêre kode moet reeds vooraf opgestel gewees het en nie 'n maand na die aanvang van bedrywighede nie. Nòg die Nasionale Vredesmag Bevelsraad nòg die Subraad oor Verdediging het die nodige ervaring gehad om 'n vredesmag bestaande uit dertien verskillende groepe saam te stel. Internasionale bystand tydens die beplanning en organisering van die Nasionale Vredesmag in plaas van tydens hul opleiding sou moontlik beter resultate gelewer het, aangesien baie van die probleme van die Nasionale Vredesmag deur swak beplanning veroorsaak is.

Lede van die Nasionale Vredesmag is vir die eerste keer op die OosRand by gedenkbyeenkomste vir Chris Hani gesien. Die Nasionale Vredesmag het onmiddellik na ontplooiing onder skoot gekom van hostelinwoners. In die eerste drie dae is vyftien mense gedood, insluitende die Suid-Afrikaanse fotograaf van die jaar, Ken Oosterbroek (32). Volgens verslaggewers het 'n Nasionale Vredesmag-lid, tydens 'n skermutseling met hostelinwoners, paniekerig geraak en wild begin skiet, waartydens Oosterbroek dan gedood is. ${ }^{88}$

Teen 20 April 1994 het 56 persone, insluitende 'n Nasionale Vredesmag-soldaat, gesterf en is 40 persone in onrusverwante geweld gewond. Die SAW is uiteindelik ingeroep om die vrede te herstel. Minder as 'n week nadat die Nasionale Vredesmag die SAW in die OosRand vervang het, is dit onttrek. ${ }^{89}$

Tyd vir seleksie, opleiding van die leiergroep, opleiding van die troepe, evaluering, heropleiding en ontplooiingsoefeninge was onvoldoende. Agt weke vir al hierdie aktiwiteite was te min. SAW- 
opleiding vir die mees basiese rekruut neem tussen 9 - 11 maande. Dit neem jare van opleiding en kundigheid om 'n doeltreffende, samehorige mag te skep. ${ }^{90}$ Die Nasionale Vredesmag is te vinnig ryp gedruk. Nog 'n probleem was dat net 'n deel van die Nasionale Vredesmag hul opleiding met erns bejeën het. Daar was manne wat gretig was om te leer, terwyl ander weer verkies het om sokker te speel of te slaap. Daar was van die begin af dissiplinêre probleme. Baie soldate wou geen opdrag uitvoer wat deur SAW-offisiere aan hulle gegee is nie. ${ }^{91}$

Opleiding van die Nasionale Vredesmag het nie rekening gehou met die basiese beginsels van groepdinamika nie. Die poging om voormalige militêre opponente in een geïntegreerde en gedissiplineerde mag saam te snoer, is hopeloos te oppervlakkig en ontoereikend aangepak. Enige goeie soldaat word opgelei om as 'n vegtende outomaat op te tree. Dit behels ' $n$ gevestigde aggressie teenoor die opponent en die dryfkrag om die opponent sonder enige empatie of gevoel van simpatie uit te wis. Die opponent is nie ' $n$ menslike wese nie, maar ' $n$ bedreigende, identiteitslose vyand. Die intregrasie van voormalige opponente in een mag is dus geen maklike taak nie. 'n Letterlike herontdekking van mekaar as menslike wesens met emosies en eie identiteite is nodig, tesame met die skepping van nuwe gemeenskaplike norme, waardestelsels, onderlinge vertroue en kameraadskap. Dit beteken die deurmaak van die strafste fisieke take waar hoë eise aan onderlinge samewerking en hulpverlening gestel word. $^{92}$

'n Belangrike faktor in die mislukking van die Nasionale Vredesmag was dus die onvermoë om voldoende samehorigheid onder die diverse elemente waaruit dié mag bestaan het, te bewerkstellig. Die Nasionale Vredesmag Bevelsraad, Subraad en -instrukteurs moes meer tyd afgestaan het aan:

- die versigtige seleksie van rekrute en offisiere gebaseer op hul ondervinding en volwassenheid;

- die bevordering van 'n gevoel van trots om lid te wees van die Nasionale Vredesmag;

- die bevordering van 'n gevoel van lojaliteit; 
- die ontwikkeling van duidelike strukture, stelsels en funksioneringsprosedure;

- die formulering van 'n gedragskode en 'n streng dissiplinêre kode; en ${ }^{93}$

- die formulering van 'n program wat vredesmaglede polities kon ontlaai.

Binne die Nasionale Vredesmag was daar lede wat steeds hulle politieke aspirasies eerste gestel het, bo die Nasionale Vredesmagkonsep. Veral voormalige MK-lede het hul identiteit van 'n mag binne 'n mag behou. ${ }^{94}$ Vir enige vredesmag om suksesvol te wees, moet dit absoluut apolities wees. Voorvalle soos voormalige MK-lede wat inligting aan Selfverdedigingseenhede deurgegee het en Tokyo Sexwale wat voormalige MK-vredesmaglede toegespreek het, is onaanvaarbaar binne die vredesmag-konsep. Dit het die Nasionale Vredesmag se geloofwaardigheid ondermyn en sy aanspraak op algehele neutraliteit onder verdenking geplaas.

Wat begin het as 'n edele idee met hoë ideale, het in 'n fiasko geëindig en soos dikwels was die politici nie ver van die wortel van die kwaad nie. Die Nasionale Vredesmag het 'n onmoontlike taak gehad. Hulle is ontplooi voordat hulle gereed was, geskeur deur interne verdeling vanweë ou vyandigheid en beroof van die leierskap wat uiters noodsaaklik was om dit in 'n doeltreffende eenheid saam te smelt. Die uiteindelike ontbinding van die Nasionale Vredesmag het die sinloosheid van dié duur oefening onderstreep.

\section{Verwysings:}

B.J. Liebenberg and S.B. Spies. (eds.), South Africa in the 20th century, Pretoria, 1993, p. 529.

Ibid.

C. Eglin. "TEC-nical transition" in Indicator SA, vol. 11, nr. 2, 1994, p. 11.

Human Sciences Research Council and Institute for Defense policy, The National Peacekeeping Force, violence on the East rand and public perceptions of the NPKF in Katorus, 1994, pp. 8-9.

5 Human Sciences Research Council and Institute for Defense Policy, p. 12.

6 M. Shaw. "The final countdown: peacekeeping and the election" in Indicator SA, Vol. 10, no. 4, 1993, P. 16. 
7 Anon.s. "Peacekeeping force: tension at the top" in Financial Mail, 21 Januarie 1994, p. 37. Die Grensoorlog was die vyandelikhede vanaf 1966 tot 1989 in die noorde van Namibiez en Suid-Angola waaraan die SAW en sy bondgenote deelgeneem het.

Human Sciences Research Council and Institute for Defense Policy, p. 13.

Beeld, 23.3.1994.

Volgens Sibanyone was Ramushwana nie 'n bate vir die Nasionale Vredesmag nie omdat hy sy eie probleme gehad het wat sy effektiwiteit as bevelvoerder gekortwiek het. Persoonlike versameling, Bandopname van onderhoud met It.kol. G. Sibanyone op 26.7.1996.

Beeld, 23.3.1994.

Human Sciences Research Council and Institute for Defense Policy, p. 13.

Ibid.

Ibid.

Ibid.

Wet op die Uitvoerende Oorgangsraad, no. 151 van 1993, p. 16.

Human Sciences Research Council and Institute for Defense Policy, p. 13.

Ibid., p. 12.

The Citizen, 11.2.1994.

Human Sciences Research Council and Institute for Defense Policy, 1994, p. 12.

J. Cilliers and G. Mills. "Time to face facts: what future for the Natinal peacekeeping force" in African Defense review, no. 14, Januarie 1994, pp. 37-38.

Selfverdedigingseenhede was vrywillige, deeltydse, gewapende eenhede vanuit die swart gemeenskap, wat in 1991 deur die ANC gewerf is in reaksie op die groeiende geweld in die "townships". D.G. Anglin. The life and death of South Africa's National Peacekeeping force, Paper presented to the Canadian research Concortium on Southern Africa, Queens University, Kingston, Canada, 1994, p. 11.

Human Sciences Research Council and Institute for Defense Policy, 1994, p. 14.

Persoonlike versameling, Bandopname van onderhoud met It.kol. J. Lubbe op 25.6.1996.

Ibid.

Anglin, p. 21.

Human Sciences Research Council and Institute for Defense Policy. p. 15.

Sunday Times, 9.1.1994.

Onbekend, "Conflict workshops for NPKF" in MPD News, vol. 3, no. 2, 1994, p. 16.

Human Sciences Research Council and Institute for Defense Policy, p. 15.

Wet op die Uitvoerende Oorgangsraad, no. 151 van 1993.

J. Cilliers and G. Mills. "Time to face facts" in African Defense Review, no. 14, Januarie 1994, p. 37.

Persoonlike versameling, Bandopname van onderhoud met It.kol. G. Sibanyone op 26.7.1996.

Anglin, p. 15.

Human Sciences Research Council and Institute for Defense Policy, p. 19.

Ibid., p. 20.

Anglin, p. 19.

Persoonlike versameling, Bandopname van onderhoud met kol. L. van Heusden op 24.6.1996. 
Persoonlike versameling, Bandopname van onderhoud met lt.kol. J. Lubbe op 25.6.1996.

Human Sciences Research Council and Institute for Defense Policy, p. 16.

Persoonlike versameling; Bandopname van onderhoud met lt.kol. J. Lubbe op 25.6.1996.

Persoonlike versameling, Bandopname van onderhoud met lt.kol. M. Burger op 3.7.1996.

Persoonlike versameling, Bandopname van onderhoud met It.kol. J. Lubbe op 25.6.1996.

Human Sciences Research Council and Institute for Defense Policy, p. 17.

Ibid., p. 16.

Ibid., p. 17.

Volgens Sibanyone het MK hoofsaaklik uit jeugdiges bestaan. Alle MK-lede het gekwalifiseer vir ' $n$ bepaalde rang op grond van die vlak van hul opleiding. Baie van die jong MK-lede het egter wel 'n gebrek aan ondervinding gehad. Persoonlike versameling, Bandopname van onderhoud met lt.kol. G. Sibanyone op 26.7.1996.

Sunday Times, 6.2.1994.

T. Motumi. "Umkhonto We Sizwe - structure, training and force levels (1984 to 1994)" in African Defense Review, no. 18, Augustus 1994, pp. 3-4.

Persoonlike versameling, Bandopname van onderhoud met kapt. A. Lloyd op 13.6.1996.

Human Sciences Research Council and Institute for Defense Policy, p. 17.

Anglin, p. 23.

Human Sciences Research Council and Institute for Defense Policy, p. 17.

Persoonlike Versameling, Bandopname van onderhoud met It.kol. J. Lubbe op 25.6.1996.

Rapport, 27.3.1994.

Anglin, p. 21.

Human Sciences Research Council and Institute for Defense Policy, p. 18.

Persoonlike Versameling, Bandopname van onderhoud met It.kol. J. Lubbe op 25.6.1996.

Human Sciences Research Council and Institute for Defense Policy, p. 18.

Persoonlike Versameling, Bandopname van onderhoud met It.kol. J. Lubbe, op 25.6.1996.

Sunday Times, 6.2.1994. Vergelyk ook Persoonlike versameling, Bandopname van onderhoud met It.kol. J. Lubbe op 25.6.1996.

Persoonlike versameling, Bandopname van onderhoud met It.kol. J. Lubbe op 25.6.1996.

Human Sciences Research Council and Institute for Defense Policy, p. 17.

The Citizen, 21.2.1994.

Ibid.

Human Sciences Research Council and Institute for Defense Policy, p. 17.

Ibid., p. 18.

The Star, 2.3.1994.

Weekly Mail and Guardian, 22-28.4.1994.

Human Sciences Research Council and Institute for Defense Policy, p. 18.

Ibid.

Ibid.

Ibid., p. 19. 


\section{The Cape Times, 11.2.1994.}

Ibid.

J. Cilliers and G. Mills. (red.), Peacekeeping in Africa, Halfway House, 1995, p. 58.

M. Shaw. International peacekeeping are there lessons for South Africa" in African Defense Review, no. 15, Maart 1994, p. 10.

Human Sciences Research Council and Institute for Defense Policy, p. 10.

J. Cilliers and G. Mills. (red.), Peacekeeping in Africa, p. 58.

M. Shaw. "International peacekeeping are there lessons for South Africa" in African Defense Review, p. 10.

Human Sciences Research Council and Institute for Defense Policy, p. 10.

D.G. Anglin. The life and death of South Africa's National Peacekeeping Force, Paper presented to the Canadian research Consortium on Southern Africa, Queens University, Kingston, Canada, 1994, p. 9.

A. Van Wyk. "Nuwe fokus op rol van vredestrukture" in RSA Oorsig, vol. 7, no. 7, 1994, p. 25 .

Anglin, p. 9.

Volgens Sibanyane het die NVM-bevelsraad ' $n$ groot aandeel in die mislukking van die NVM gehad, omdat hulle nie hulle opdrag behoorlik uitgevoer het nie, so byvoorbeeld moes die NVM-bevelsraad volgens die Wet op Uitvoerende Oorgansraad maatstawwe vir die werwing en keuring van vredesmaglede bepaal het - dit is egter nooit uitgevoer nie. Die NVM-bevelsraad het ook nie genoegsame beheer oor die verrigtinge op De Brug gehad nie. Persoonlike Versameling, Bandopname van onderhoud met Lt.kol. G. Sibanyane op 26.7.1996.

Human Sciences Research Council and Institute for Defence Policy, p. 24.

Persoonlike versameling, Bandopname van onderhoud met It.kol. J. Lubbe op 25.6.1996.

Die Volksblad, 15.4.1994.

Human Sciences Research Council and Institute for Defense Policy, p. 22.

Human Sciences Research Council and Institute for Defense Policy, p. 23.

Rapport, 22.5.1994.

Die Volksblad, 8.2.1994.

Onbekend, "Peace keeping force: tension at the top" in Financial Mail, p. 37.

Persoonlike Versameling, Bandopname van onderhoud met kol. L. van Heusden op 24.6.1996. Vergelyk ook Persoonlike Versameling, Bandopname van onderhoud met lt.kol. G. Sibanyone op 26.7.1996. 